REVIEW

\title{
Genetic hyperthyroidism: hyperthyroidism due to activating TSHR mutations
}

\author{
A Hébrant, W C G van Staveren, C Maenhaut, J E Dumont and J Leclère ${ }^{1}$ \\ School of Medicine, Institute of Interdisciplinary Research (IRIBHM), Free University of Brussels, Campus Erasme, Route de Lennik 808 , B-1070 \\ Brussels, Belgium and ${ }^{1}$ Centre Hospitalier Universitaire (CHU) de Nancy, 54035 Nancy, France
}

(Correspondence should be addressed to JE Dumont; Email: jedumont@ulb.ac.be)

\begin{abstract}
Three syndromes affecting the thyroid gland are described in the literature separately: familial nonautoimmune hyperthyroidism, sporadic congenital nonautoimmune hyperthyroidism, and autonomous adenomas. Recent studies have shown that these three syndromes are caused by similar activating mutations of the TSH receptor gene (TSHR), and that the consequences of these mutations on the physiology and gene expression of the thyroid are qualitatively, but not quantitatively, similar. The three syndromes and two suggested unrecognized variants are in fact facets of the same disease, genetic hyperthyroidism due to TSHR mutations, the expression of which depends on the intensity of activation, its timing, and on the number of affected cells.
\end{abstract}

European Journal of Endocrinology 164 1-9

\section{Introduction}

The first description of familial nonautoimmune hyperthyroidism (FNAH) was published in $1982(1,2)$. FNAH is also called hereditary toxic thyroid hyperplasia or autosomal dominant autoimmune hyperthyroidism. It is hereditary through dominant activating mutation of the TSH receptor (TSHR) affecting all thyroid cells. A similar pathophysiology between autonomous adenomas (AAs; (benign hyperfunctioning tumor)). Owing to mutations (mostly TSHR), activating the TSH-cAMP cascade affects one cell clonally expanded in an adenoma or nonencapsulated nodule. Inactivating mutations of genes of signal transduction negatively controlling the TSH receptor cAMP pathway (e.g. phosphodiesterases) would give the same result and FNAH was suggested by two features: the tissues of the two diseases have the same histological aspect (1) and contrary to those provided by Graves' cases, these tissues remain hyperfunctioning after being grafted into nude mice (3). This hypothesis was confirmed in 1994 by the identification of the mechanism of this particular form of thyrotoxicosis, an activating mutation of TSH receptor (TSHR) (4). The first case of a sporadic neomutation causing congenital hyperthyroidism was described in 1995 leading to the so-called 'sporadic' or 'sporadic congenital nonautoimmune hyperthyroidism (SCNAH; these are germline neomutations affecting all thyroid cells.)' form of the disease (5). A large fraction of AAs are also caused by activating mutations of the TSHR (6). Thus, activating mutations of the TSHR are the cause of the three syndromes: FNAH, SCNAH, and AA. While in the first two syndromes the mutation affects all thyroid cells, in AA it affects only one cell at the clonal origin of the benign tumor (7). The three syndromes, resulting from activating mutations of the TSHR, are the facets of one disease, genetic hyperthyroidism due to TSHR mutations (Fig. 1) (8). In this review, we describe the clinical and physiopathological aspects of this disease. The clinical hallmarks of FNAH and SCNAH have been analyzed in more detail in a recent review (9).

\section{FNAH and SCNAH: clinical and biological characteristics}

Based on the first five families comprising 49 patients suffering from FNAH, the clinical profile corresponding to the activating germline mutations of the TSHR was described in 1997 (10). The knowledge of the different clinical aspects of this disease is of crucial importance because they lead to suspect the diagnosis. The description may now be revisited, thanks to the increasing number of newly reported FNAH and SCNAH cases $(2-4,11,12)$. In this review, we analyze the medical history of 152 FNAH coming from 27 families and 15 SCNAH caused by germline neomutations of the TSHR (Supplementary Tables 1 and 2 , see section on supplementary data given at the end of this article). 


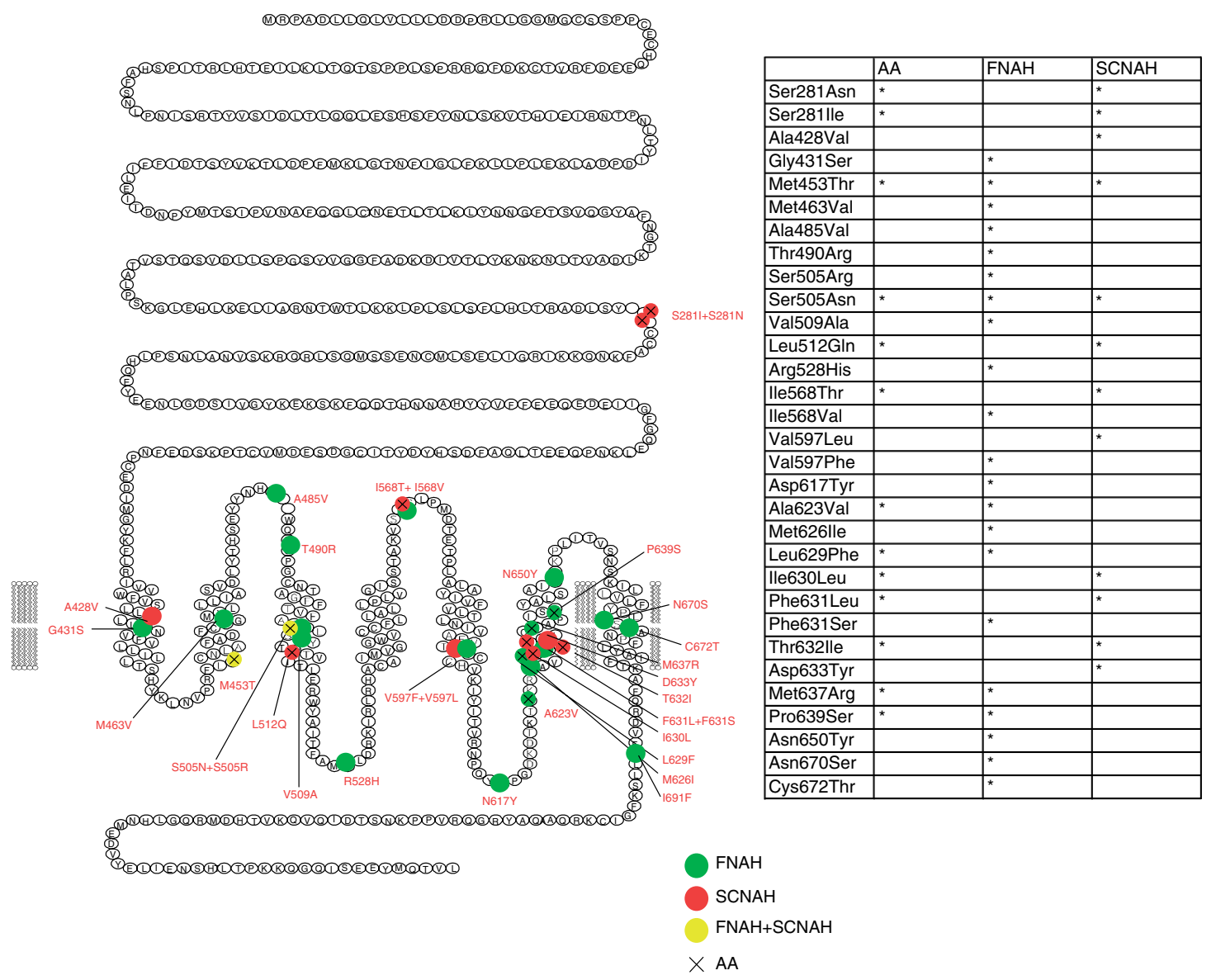

Figure 1 Activating mutations on TSHR gene in the various genetic hyperthyroidism syndromes. Comparison of amino acid structure of the TSHR and locations of gain-of-function mutations found in FNAH (green), in SCNAH (red), or in FNAH and SCNAH (yellow). TSHR mutations also found in AA are encircled in blue. TSHR mutations found in AA only are not indicated.

\section{Prevalence of the disease}

The demographic prevalence is difficult to evaluate and is likely to be underestimated. This underestimation will be progressively reduced, thanks to a better knowledge of the characteristics of the disease. This is attested by the increasing number of cases by years: 2 families with FNAH between 1982 and 1993, 6 families with FNAH and 8 isolated cases of SCNAH between 1994 and 1999, and 19 families with FNAH and 7 isolated cases of SCNAH since 2000. The majority of cases have been reported in Europe, whereas only two FNAH and three SCNAH have been reported in the United States. This discrepancy could be due to the different approaches in the treatment of hyperthyroidism, which is more radical in the United States (surgery and radioiodine) than in Europe, where antithyroid drugs are widely used. Under the former treatment, the typical tendency to recur is more easily masked, as such recurrences are precluded by the removal or destruction of responsible thyroid cells.
Consistent with the autosomal dominant inheritance, there is no sexual predominance: 69 males and 83 females in the familial form, as in the congenital form ( 7 males, 7 females, and sex is not indicated in 1 case).

\section{Onset of thyrotoxicosis}

The time of recognition of the clinical signs is highly variable, depending in part on the intensity of the activating mutant allele.

\section{Thyroid volume}

The thyroid size or morphology is highly variable as indicated in 97 cases: a normal thyroid volume is present in only 25 cases, and a goiter is present in the 72 others. The goiter is either homogeneous $(57 / 72)$ or multinodular (15/72). By comparing with the natural history of goitrogenesis due to chronic TSH stimulation, it would be logical to consider that the thyroid 
structure will depend on the age of diagnosis. In the youngest patients, the thyroid is normal or slightly increased, thereafter a homogenous goiter appears and tends to develop multinodularity later. In fact, the situation is more complex since a goiter was already observed at birth in 5 out of 14 of SCNAH (the morphology was not indicated in one case) $(5,13-16)$. This discrepancy could be due to the type of TSHR gene mutation leading to a variable intensity of activation. However, this assumption does not explain the different aspects of thyroids encountered independently of age in a same family with the same mutation (normal thyroid volume, diffuse, or multinodular goiter) (Supplementary Table 1 , see section on supplementary data given at the end of this article). Insulin-like growth factor 1 (IGF1) supply and other genetic, epigenetic, and environmental factors are probably the modifying factors $(6,17)$.

\section{Pathology}

By light microscopy, a diffuse hyperplasia is encountered when the thyroid volume is normal or in case of a homogenous goiter $(1,11,18-21)$. The general aspect is completely different from Graves' tissue due to the absence of any lymphocytic infiltrate or inflammatory features and the diagnosis must be suspected already from this routine examination when histological evaluation is possible $(1,2)$. The thyroid tissue of FNAH and SCNAH consists in clusters of small hyperactive follicles alternating with the areas of large follicles constituted by flat cells. This aspect is similar to toxic AA tissue, which led us to suggest the term 'toxic thyroid hyperplasia' (1). Immunohistology is not usually performed and is not necessary for the diagnosis. The absence of Graves' tissue characteristics, the absence of activated $\mathrm{T}$ and $\mathrm{B}$ lymphocytes, the absence of aberrant expression of HLA II antigens by the thyroid cells, the absence of deposits of immunoglobulins, exclude Graves' disease diagnosis, but the presence of autoimmune reactions does not exclude SCNAH (1). The pathologic aspects are less characteristic in patients harboring multinodular goiters. In these cases, necrotic or hemorrhagic events could lead to the development of inflammation and of areas invaded by macrophages and a few inflammatory cells.

The early, constant, and unregulated stimulation of thyroid cells by the activated mutated TSHR raises the question of the risk of thyroid cancer. Sixty-seven thyroid ablations have been realized, and only three cancers were found: two of micropapillary structure (2) and one oncocytic carcinoma (19). It is impossible to assert any relevance concerning the association of the two diseases. The small number of thyroid cancers is consistent with their low frequency in other cases of chronic TSHR activation, i.e. in AAs and in Graves' disease (8).

\section{Ophthalmopathy}

Thyroid ophthalmopathy is still considered as a specific sign of Graves' disease (with the exception of a few cases of Hashimoto's disease) and mainly linked with the presence of activating TSHR antibodies (thyroid stimulating immunoglobulins (TSI; that cause autoimmune hyperthyroidism (Graves' disease))). A positive correlation between the levels of TSI and the severity of ophthalmopathy has been demonstrated long back and has been recently reemphasized (22). For this reason, the absence of any sign of ophthalmopathy in the two first families $(1,11)$ was not surprising and led us to consider this absence as a major marker of FNAH (10). Later on, this assertion has not been confirmed as 20 cases of 83 FNAH patients presented ocular symptoms. The ocular symptoms are differently described: proptosis (23), exophthalmia (11), prominence (3), and staring eyes (2). These ocular signs always affect young patients and are particularly frequent $(8 / 10)$ in SCNAH patients. It is important to note the absence of any inflammatory features in all these cases. The ocular signs, in particular proptosis, could be due to the specific anatomy of the infant orbit where the external wall is less prominent than in the adult. The horizontal bicanthal line, the reference to appreciate the proptosis in adults, might not be adequate in the neonate or in very young children. It is noteworthy that when proptosis is present, a computer tomographic examination does not show any enlargement of ocular muscles (24-26). Another hypothetical explanation for proptosis could be the activation of the TSHR mimicking the effects of TSI on orbital structures. The reported presence of TSHR on orbital fibroblasts (27) and adipocytes (28), as well as the production of hyaluronan by orbital preadipocytes transfected with an activating mutant TSHR (29), suggest the possibility that ophthalmopathy may develop in the absence of TSI by a constitutive activation of these receptors. The case reported by Lavard bears against this hypothesis, because inspite of three relapses and the administration of four successive doses of radioiodine, the exophthalmia decreased progressively and disappeared at the age of 18 years (30). The ocular symptoms are always relatively weak and without any of the inflammatory components of Graves' ophthalmopathy.

\section{Circulating thyroid antibodies}

By definition, TSI are not relevant to the pathophysiology of the disease, but their presence remains conceivable in patients genetically predisposed to autoimmunity. Antithyroperoxidase and/or antithyroglobulin antibodies have been found in three families but TSHR antibodies were always absent $(18,21,31)$. The association of a constitutive activating TSHR mutation and thyroid autoimmunity remains exceptional but is of particular interest because the presence 
of such antibodies could lead to the erroneous diagnosis of Graves' disease (18). The index patient of the family described by Vaidya et al. (21) had no eye signs but the TSH-binding inhibitory immunoglobulins (TBII) were 'borderline' positive. Consequently, the presence of low levels of thyroid antibodies does not exclude the diagnosis if it is presented with some other features. The absence of TSI detected by the new commercial assays measuring TBII is important as the prevalence of TBII negative in Graves' patients is estimated to be around 5\% with the new generation TBII kits (32). Thus, the risk to confuse the two diseases is low and is avoidable if the clinical context is considered but there are still borderline cases.

\section{Resistance to conventional treatments}

Owing to the frequent confusion with Graves' disease, the majority of the patients have been treated by conventional treatments: antithyroid drugs, partial thyroidectomy, or limited doses of radioiodine. Sixtyseven patients were followed up after the withdrawal of these treatments: all had one or several relapses. This can be a clue but many Graves' disease patients also have relapse. The only way to avoid these relapses is to destroy all the thyroid tissue by either total thyroidectomy alone or in combination with radioiodine. If a total thyroidectomy is considered as being too aggressive in the youngest children, then a sustained treatment with antithyroid drugs is necessary until a more appropriate age for surgery. In some cases, antithyroid drugs poorly control thyrotoxicosis and the patients remain in subclinical hyperthyroidism $(12,15$, 31, 33, 34).

\section{Particular aspects of SCNAH}

The neonatal expression of the disease can be seen both in some FNAH and in most SCNAH. De novo mutations occurred in $15 \operatorname{SCNAH~}(5,12,13), 10$ of them presented thyrotoxicosis at birth and 4 of them were diagnosed at 5th, 8th, 9th, and 11th months of age (the age was not indicated in 1 case). The SCNAH are referred to as 'sporadic' congenital nonautoimmune thyrotoxicosis. Obviously, this denomination is relatively inappropriate because these neomutants if properly treated would be able to transmit the disease to their descendants. This is clearly demonstrated in three families $(23,35,36)$ where the less severe mutations led to a delayed diagnosis. The early age of clinical manifestation indicates a more severe phenotype, presumably related to a higher activation of the receptor.

The characteristics of the congenital form is well detailed in 14 of the 15 SCNAH children: prematurity (10/14), low birth weight (12/14), small goiter (5/14), craniosynostosis (7/14), and mental retardation (6/10). As mentioned above, the eye signs are frequent.
However, these symptoms are not specific and can also be seen in neonatal autoimmune Graves' thyrotoxicosis. The two key elements in the diagnosis of neonatal nonautoimmune thyrotoxicosis are the absence of TBII and the persistence of hyperthyroidism beyond 3 months after birth. Neonates with hyperthyroidism due to placental transmission of maternal TSI are usually treated with antithyroid drugs around 3 months until the disappearance of maternal TSI. Here, contrary to what happens in the descendants of Graves' disease patients, there is a systematic recurrence of hyperthyroidism after this period, which must raise the diagnosis of SCNAH and requests a TSHR mutation research.

In summary, the clinical and biological profiles of FNAH present sufficient characteristics to easily identify this entity: autosomal dominant transmission, frequency of the disease around $50 \%$ in the families, early onset of the clinical hyperthyroidism in the new generations, ocular signs attenuated and only seen in youngest patients, exceptional presence of circulating thyroglobulin and thyroperoxydase antibodies, absence of TSI, and remarkable tendency to relapse after conventional treatments given to the children of Graves' disease patients. In the SCNAH, the appearance of ophthalmopathy does not exclude the diagnosis, which will be quickly made by the absence of thyroid immunity in the mother and the persistence of thyroid hyperfunction after the first weeks of life.

\section{AAs: clinical and biological characteristics}

The clinical phenotype and biology of AAs have been extensively studied (6). To summarize, constitutive activation of the TSHR-cAMP cascade leads to hyperfunction and growth of the cells as a well encapsulated adenoma or nonencapsulated nodule (14). Owing to functional hyperactivation and higher sodium iodide symporter (NIS) expression, the lesions will take up more radioiodide or pertechnetate than the surrounding tissue generating the scintigraphic aspect of a 'hot' nodule. Depending on the size of the lesion and the dietary iodide supply, autonomous thyroid hormone secretion will decrease by the negative feedback of the TSH levels and thereby decrease the stimulation and activity of the noninvolved thyroid tissue (quiescent tissue), which will take up less radioiodide. With increasing mass and/or iodide supply, the nodule may secrete more hormone than normal and thus induce thyrotoxicosis $(6,37)$. Other mutations leading to the activation of the TSH-cAMP cascade in one cell will lead to the same phenotype, i.e. activating mutations of $\mathrm{G}_{\mathrm{s}} \alpha$ have been detected in $5-10 \%$ of the adenomas while the TSHR account for about $70-80 \%(37-39)$. The cause of $20-30 \%$ of these adenomas is still unknown. A toxic AA in neonate 
presents of course the same phenotypes as SCNAH or FNAH except for the presence of a nodule rather than diffuse hyperplasia (40).

AA tissues in vitro, when compared with their control quiescent tissues, appear more stimulated with a higher radioiodide uptake, spontaneous thyroxine secretion, and NIS and thyroperoxidase expression than the extratumoral quiescent tissue (41). However, their cAMP level is barely, if at all, increased (42).

\section{Comparative biology of FNAH, SCNAH, and $A A$}

The gene expression characteristics of pathological tissues of FNAH and AA have been extensively studied. These characteristics are consistent with our knowledge of the role of the TSH-cAMP cascade in thyrocytes (Fig. 2) (8). They are similar in both types of tissues but much less marked in FNAH cells. More than 90\% of regulated genes in FNAH were significantly regulated in the same direction in AA, which underlines their common molecular causes. However, some genes were only regulated only in AA in agreement with the fact that in this case only a fraction of the tissue causes hyperthyroidism. Among the genes downregulated in both thyroid lesions, 76\% were more downregulated in AA than in FNAH. A majority of all these regulations

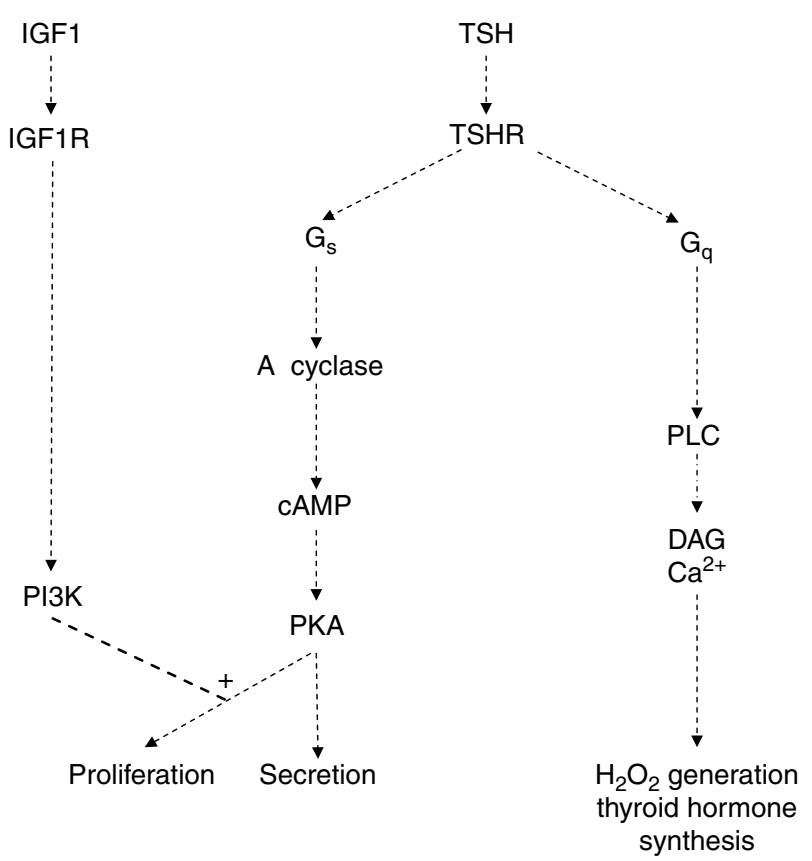

Figure 2 Signal transduction in the human thyroid (simplified version). $\mathrm{G}_{\mathrm{s}}, \mathrm{G}_{\mathrm{q}}$, GTP-binding proteins; PKA, cAMP-dependent protein kinase; A cyclase, adenylate cyclase; PLC, phospholipase C; DAG, diacylglycerol; IGF1, insulin-like growth factor 1; PI3K, phosphatidylinositol 3 kinase. are downregulations. In both tissues a large proportion of the downregulated genes concern lymphocytes and proteins involved in inflammation, which is consistent with pathological findings. Among the genes regulated only in AA, most are involved in intermediary metabolism (8). For many of these, similar, but not statistically significant, effects were observed in FNAH tissue.

Except for the higher sensitivity of FNAH compared with normal tissue for the growth effects of TSH, there is little evidence at the functional level of a higher stimulation of the FNAH tissue (8). As in AA, their cAMP level is not measurably increased. This counterintuitive finding is easily explainable by several facts. First, the high variability of results from different tissues would blur small effects. Second, higher levels of cAMP in only some cells at a given time would be masked in measurements on the whole cell population. Third, the enhancement of cAMP concentration necessary to achieve a maximal stimulation of a function (i.e. secretion) is only a factor of 2 (43). FNAH tissues respond similarly to normal tissue to TSH and forskolin with regard to cAMP levels, inositol phosphate generation, $\mathrm{H}_{2} \mathrm{O}_{2}$ generation, and iodide organification (8). In fact, apart from the enhanced iodide trapping and the consequent higher hormone synthesis and secretion in adenoma they show little evidence of functional activation. In this regard, the FNAH phenotype is much milder than the AA. The reason why the chronic stimulation by the TSHR would achieve rather small cAMP responses can be multiple. Negative feedbacks are induced by the stimulation: i) probable downregulation of the receptor levels as in COS7 cells transfected with cDNA of constitutively activated receptors (44); ii) demonstrated direct activation and induction of cAMP phosphodiesterases; iii) induction of G-protein-coupled receptor kinases (45); and iv) induction of RGS2 inhibiting adenylate cyclase in human thyroid cells (46).

The much earlier age of occurrence of SCNAH versus FNAH also indicates a much more severe disease in the former (i.e. suggesting stronger activating mutations). The pathology of the tissue is similar to an increased vascularization and absence of lymphocytes, i.e. obvious indirect effects of the TSHcAMP cascade. With regard to the growth effect, one cell at the origin of the AA must have divided at least 30 times without loss to achieve a size of $1 \mathrm{~g}$. This is consistent with a higher, although still low, proportion of Ki67-labeled cells (i.e. cycling cells) in the AA than in normal tissue (41). On the other hand, the cells in FNAH achieve a size of 2-3 times of a normal thyroid, i.e. a few divisions more than a normal thyroid. Thus, the level of thyrocyte stimulation is much lower in FNAH than that in AA. This is also evident clinically as the lower levels of hyperthyroidism are achieved by the whole thyroid in the FNAH than by a nodule in the AA. There is not a strict correlation between what we 
know of the strength activation of the TSHR and phenotype. This is explained by several confounding factors including dietary iodide intake, volume of the affected tissue, level of negative intracellular feedback signaling, or epigenetic effects of chronic stimulation $(6,46)$. This is strikingly illustrated by the very different ages of onset of the FNAH manifestation for subjects within the same family.

The possible role of the TSHR activation of the $\mathrm{G}_{\mathrm{q}}$-phospholipase C (PLC), $\mathrm{Ca}^{2+}$ diacylglycerol cascade, has been less investigated. For the mutated receptors of AAs investigated, only few of the several demonstrated mutations presented some constitutive activation of the cascade in transfected COS cells, which shows that activation of this pathway is not necessary (44, 47, 48). Moreover, the $\mathrm{H}_{2} \mathrm{O}_{2}$ generation and the dependent iodide organification is neither enhanced in the FNAH tissue nor is the iodide organification capacity in the AA tissue $(41,42)$. Hot nodules display a significant iodide leak (49). Finally, half of AA studied in vivo displayed a positive $\mathrm{NaClO}_{4}$ test, i.e. a relative defect in iodination (50). Thus, stimulated tissues in FNAH and AA produce more thyroid hormone because at normal iodide level $(<1 \mu \mathrm{M})$ they take up more iodide, the limiting step in total iodide organification, but not because of a stimulation of the organification step itself, i.e. of $\mathrm{H}_{2} \mathrm{O}_{2}$ generation or its activating $\mathrm{G}_{\mathrm{q}}-$ PLC cascade.

All the effects of the activating mutations of the TSHR can be accounted for by the stimulation of the cAMP cascade: increased iodide uptake by the induction of NIS, increased thyroid hormone secretion, and thyroid growth (http://www.thyroidmanager.org/). Indeed, similar effects result from constitutive activation of $\mathrm{G}_{\mathrm{s}}$ in AAs (51), in the McCune-Albright syndrome, and in mice thyroid expressing the $\mathrm{G}_{\mathrm{s}}$-specific adenosine $\mathrm{A} 2$ receptor (52). Moreover, the growth effects of TSH on human thyroid cells in culture are fully reproduced by forskolin, a specific activator of adenylate cyclase (53). Nevertheless, the role of the $\mathrm{G}_{\mathrm{q}}-\mathrm{PLC}$ cascade should be investigated in a systematic study of the effects of all mutations of TSHR on this cascade. Indeed, some activity of this cascade is required for goitrogenesis in mice thyroids (54). In human thyroid, defects in $\mathrm{G}_{\mathrm{q}}$ stimulation and consequently of iodination, an important compensatory TSH stimulation, but not goitrogenesis, is observed (55). Later, Winkler et al. (56) reported a TSHR-activated mutation with decreased stimulation of $G_{q}$ but as evidenced by normal or elevated serum thyroid hormone levels no defect in iodination and no goiter were observed. In both cases, the basal IP generation is unaffected. Winkler et al. (56) suggested a necessary role for the $\mathrm{G}_{\mathrm{q}}$ cascade in goitrogenesis. It is interesting, in this regard, that in dog, stimulation of this cascade may replace IGF1 as the necessary complement of cAMP in the stimulation of proliferation (57). However, this does not explain the AAs caused by $G_{s}$ activation or by TSHR mutation activating $G_{s}$ but not $\mathrm{G}_{\mathrm{q}}(51)$.

\section{The concept of genetic hyperthyroidism due to TSHR mutations}

Qualitatively, similar activating dominant TSHR mutations account for FNAH, SCNAH, and AA. Some AAs are caused also by activating mutations of $\mathrm{G}_{\mathrm{s}} \alpha$. Hyperthyroidism in the McCune-Albright syndrome, due to activating mutations of the $\mathrm{G}_{\mathrm{s}} \alpha$ protein, i.e. downstream of TSHR, could be included in the definition of genetic hyperthyroidism. However, the McCune-Albright syndrome is a more complex multiorgan disease with a somatic mosaicism and hyperthyroidism is found only in a fraction of patients (58). Mutation of the TSHR conferring sensitivity to human chorionic gonadotrophin (hCG) and LH also causes a temporary hyperthyroidism pregnancy (59).

The differences between the pathologies are mostly related to the unicellular or whole organ expression of the mutation and on the intensity of the activation. To induce an AA from a mutation in one cell, the activation must be high; a low level of activation

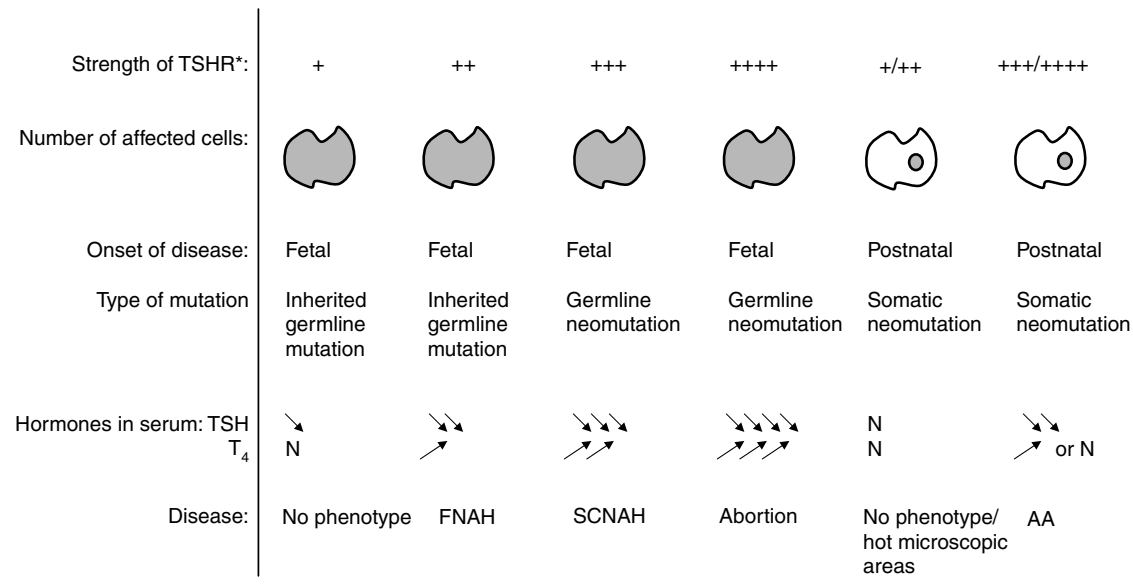

Figure 3 Forms of genetic hyperthyroidism depending on the strength of the activation by mutated TSHR, the number of affected cells (one cell or the whole thyroid), and the onset of mutation (hereditary, congenital sporadic, or postnatal). 
would only decrease the level of TSH or if lower may just lead to a not discernable small locus of hyperplasia. Congenital mutations affecting all thyroid cells cause FNAH and SCNAH (Fig. 3). The fact that SCNAH hyperthyroidism appears early in life, and that there are common mutations between SCNAH and AA but less between FNAH and AA suggests that SCNAH mutations are stronger than those of FNAH. One might presume that even stronger mutations would kill the fetus before birth. In addition, the mutations of SCNAH, although they could become familial now that we could cure the affected patients, would not have allowed the survival of the patients before, and therefore their transmission. Thus, one can postulate a continuum in the strength of the activation by the TSHR in genetic hyperthyroidism with different consequences when they affect one cell or the whole cell population (Fig. 3). Two, as not yet identified, syndromes should be looked for very active TSHR congenital neomutations leading to fetal death and abortion, and mild familial hereditary mutations leading to only a relative decrease in serum TSH levels with no hyperthyroidism. Increased sensitivity of TSHR to TSH would also lead to the latter phenotype. Relatively low serum TSH values could allow to detect such cases, just as a lower cut off has led to the detection of many previously undiagnosed cases of congenital hypothyroidism (60). Similarly, mild activating mutations in single thyroid cells may give rise to small autonomous areas with high radioiodide uptake with no general consequences (61).

There are still outstanding questions. A systematic study of the strength of all TSHR activating mutations as well as their effects on the $\mathrm{G}_{\mathrm{q}}-\mathrm{PLC}$ cascade would constitute the best basis to correlate biology and phenotype (as done in $(47,55)$ ). The hypothesis that a population of normal people with relatively low TSH level would correspond to defined genetic polymorphisms in TSHR sequences could be looked for as well as the possibility of mild FNAH in old patients developing hyperthyroidism with negative TSAb (62). Finally, the possibility of new TSHR strong activating neomutations in cases of spontaneous abortions may be examined. As discrete TSHR localization and role in different tissues are now discovered, it will be of interest for clinicians to look for anomalies in these tissues and functions in both FNAH and SCNAH (e.g. white adipose tissue, ovary, brain, etc.) (63-65).

\section{Supplementary data}

This is linked to the online version of the paper at http://dx.doi.org/10. 1530/EJE-10-0775.

\section{Declaration of interest}

The authors declare that there is no conflict of interest that could be perceived as prejudicing the impartiality of the research reported.

\section{Funding}

This work was supported by various grants of the Fonds National de la Recherche Scientifique (FNRS) et Fonds de la Recherche Scientifique Médicale (FRSM) in Belgium, Fondation belge de la Vocation, Action Concertée de la Communauté Française, and from INSERM in France.

\section{Acknowledgements}

The authors acknowledge the contribution of Dr R Coutain and J M Limal (Angers) for giving the FNAH samples who had not been, by mistake, thanked in the previous research article.

\section{References}

1 Leclere J \& Thomas JL. Diffuse nonautoimmune hyperthyroidism. Annales d'Endocrinologie 198243 553-568.

2 Thomas JS, Leclere J, Hartemann P, Duheille J, Orgiazzi J, Petersen M, Janot C \& Guedenet JC. Familial hyperthyroidism without evidence of autoimmunity. Acta Endocrinologica 1982100 512-518. (doi:10.1530/acta.0.1000512)

3 Leclere J, Bene MC, Duprez A, Faure G, Thomas JL, Vignaud JM \& Burlet C. Behaviour of thyroid tissue from patients with Graves' disease in nude mice. Journal of Clinical Endocrinology and Metabolism 198459 175-177. (doi:10.1210/jcem-59-1-175)

4 Duprez L, Parma J, Van Sande J, Allgeier A, Leclere J, Schvartz C, Delisle MJ, Decoulx M, Orgiazzi J \& Dumont J. Germline mutations in the thyrotropin receptor gene cause non-autoimmune autosomal dominant hyperthyroidism. Nature Genetics 19947 396-401. (doi:10.1038/ng0794-396)

5 Kopp P, Van Sande J, Parma J, Duprez L, Gerber H, Joss E, Jameson JL, Dumont JE \& Vassart G. Brief report: congenital hyperthyroidism caused by a mutation in the thyrotropin-receptor gene. New England Journal of Medicine 1995332 150-154. (doi:10.1056/NEJM199501193320304)

6 Corvilain B, Van Sande J, Dumont JE \& Vassart G. Somatic and germline mutations of the TSH receptor and thyroid diseases. Clinical Endocrinology 200155 143-158. (doi:10.1046/j.13652265.2001.01365.x)

7 Krohn K, Fuhrer D, Holzapfel HP \& Paschke R. Clonal origin of toxic thyroid nodules with constitutively activating thyrotropin receptor mutations. Journal of Clinical Endocrinology and Metabolism 199883 130-134. (doi:10.1210/jc.83.1.130)

8 Hebrant A, Van Sande J, Roger PP, Patey M, Klein M, Bournaud C, Savagner F, Leclere J, Dumont JE, van Staveren WC \& Maenhaut C. Thyroid gene expression in familial nonautoimmune hyperthyroidism shows common characteristics with hyperfunctioning autonomous adenomas. Journal of Clinical Endocrinology and Metabolism 200994 2602-2609. (doi:10.1210/jc.2008-2191)

9 Gozu HI, Lublinghoff J, Bircan R \& Paschke R. Genetics and phenomics of inherited and sporadic non-autoimmune hyperthyroidism. Molecular and Cellular Endocrinology 2010322 125-134. (doi:10.1016/j.mce.2010.02.001)

10 Leclere J, Bene MC, Aubert V, Klein M, Pascal-Vigneron V, Weryha G \& Faure G. Clinical consequences of activating germline mutations of TSH receptor, the concept of toxic hyperplasia. Hormone Research 199747 158-162. (doi:10.1159/000185459)

11 Horton GL \& Scazziga B. Hereditary hyperthyroidism with diffuse non autoimune hyperactivity due to autonomy of function and growth. Annales d'Endocrinologie 19874892.

12 Watkins MG, Dejkhamron P, Huo J, Vazquez DM \& Menon RK. Persistent neonatal thyrotoxicosis in a neonate secondary to a rare thyroid-stimulating hormone receptor activating mutation: case report and literature review. Endocrine Practice 200814 479-483.

13 de Roux N, Polak M, Couet J, Leger J, Czernichow P, Milgrom E \& Misrahi M. A neomutation of the thyroid-stimulating hormone 
receptor in a severe neonatal hyperthyroidism. Journal of Clinical Endocrinology and Metabolism $1996 \mathbf{8 1}$ 2023-2026. (doi:10. 1210/jc.81.6.2023)

14 Tonacchera M, Agretti P, Rosellini V, Ceccarini G, Perri A, Zampolli M, Longhi R, Larizza D, Pinchera A, Vitti P \& Chiovato L. Sporadic nonautoimmune congenital hyperthyroidism due to a strong activating mutation of the thyrotropin receptor gene. Thyroid 2000 10 859-863. (doi:10.1089/thy.2000.10. 859)

15 Bircan R, Miehle K, Mladenova G, Ivanova R, Ivanova R, Sarafova A, Borissova AM, Lublinghoff J \& Paschke R. Multiple relapses of hyperthyroidism after thyroid surgeries in a patient with long term follow-up of sporadic non-autoimmune hyperthyroidism. Experimental and Clinical Endocrinology and Diabetes 2008 116 341-346. (doi:10.1055/s-2007-1004566)

16 Chester J, Rotenstein D, Ringkananont U, Steuer G, Carlin B, Stewart L, Grasberger H \& Refetoff S. Congenital neonatal hyperthyroidism caused by germline mutations in the TSH receptor gene. Journal of Pediatric Endocrinology and Metabolism 200821 479-486.

17 Clement S, Refetoff S, Robaye B, Dumont JE \& Schurmans S. Low TSH requirement and goiter in transgenic mice overexpressing IGF-I and IGF-Ir receptor in the thyroid gland. Endocrinology 2001 142 5131-5139. (doi:10.1210/en.142.12.5131)

18 Fuhrer D, Warner J, Sequeira M, Paschke R, Gregory J \& Ludgate M. Novel TSHR germline mutation (Met463Val) masquerading as Graves' disease in a large Welsh kindred with hyperthyroidism. Thyroid 200010 1035-1041. (doi:10.1089/ thy.2000.10.1035)

19 Karges B, Krause G, Homoki J, Debatin KM, de Roux N \& Karges W. TSH receptor mutation V509A causes familial hyperthyroidism by release of interhelical constraints between transmembrane helices TMH3 and TMH5. Journal of Endocrinology 2005186 377-385. (doi:10.1677/joe.1.06208)

20 Supornsilchai V, Sahakitrungruang T, Wongjitrat N, Wacharasindhu S, Suphapeetiporn K \& Shotelersuk V. Expanding clinical spectrum of non-autoimmune hyperthyroidism due to an activating germline mutation, p.M453T, in the thyrotropin receptor gene. Clinical Endocrinology 2009 70 623-628. (doi:10. 1111/j.1365-2265.2008.03367.x)

21 Vaidya B, Campbell V, Tripp JH, Spyer G, Hattersley AT \& Ellard S. Premature birth and low birth weight associated with nonautoimmune hyperthyroidism due to an activating thyrotropin receptor gene mutation. Clinical Endocrinology 200460 711-718. (doi:10.1111/j.1365-2265.2004.02040.x)

22 Gerding MN, Van Der Meer JW, Broenink M, Bakker O, Wiersinga WM \& Prummel MF. Association of thyrotrophin receptor antibodies with the clinical features of Graves' ophthalmopathy. Clinical Endocrinology 2000 52 267-271. (doi:10.1046/ j.1365-2265.2000.00959.x)

23 Schwab KO, Gerlich M, Broecker M, Sohlemann P, Derwahl M \& Lohse MJ. Constitutively active germline mutation of the thyrotropin receptor gene as a cause of congenital hyperthyroidism. Journal of Pediatrics 1997131 899-904. (doi:10.1016/ S0022-3476(97)70040-4)

24 Khoo DH, Parma J, Rajasoorya C, Ho SC \& Vassart G. A germline mutation of the thyrotropin receptor gene associated with thyrotoxicosis and mitral valve prolapse in a Chinese family. Journal of Clinical Endocrinology and Metabolism 199984 1459-1462. (doi:10. 1210/jc.84.4.1459)

25 Ferrara AM, Capalbo D, Rossi G, Capuano S, Del Prete G, Esposito V, Montesano G, Zampella E, Fenzi G, Salerno M \& Macchia PE. A new case of familial nonautoimmune hyperthyroidism caused by the M463V mutation in the TSH receptor with anticipation of the disease across generations: a possible role of iodine supplementation. Thyroid 200717 677-680. (doi:10. 1089/thy.2006.0333)

26 Kopp P, Jameson JL \& Roe TF. Congenital nonautoimmune hyperthyroidism in a nonidentical twin caused by a sporadic germline mutation in the thyrotropin receptor gene. Thyroid 1997 7 765-770. (doi:10.1089/thy.1997.7.765)
27 Paschke R, Vassart G \& Ludgate M. Current evidence for and against the TSH receptor being the common antigen in Graves' disease and thyroid associated ophthalmopathy. Clinical Endocrinology 199542 565-569. (doi:10.1111/j.1365-2265.1995. tb02681.x

28 Kumar S, Coenen MJ, Scherer PE \& Bahn RS. Evidence for enhanced adipogenesis in the orbits of patients with Graves' ophthalmopathy. Journal of Clinical Endocrinology and Metabolism 200489 930-935. (doi:10.1210/jc.2003-031427)

29 Zhang L, Bowen T, Grennan-Jones F, Paddon C, Giles P, Webber J, Steadman $\mathrm{R}$ \& Ludgate $\mathrm{M}$. Thyrotropin receptor activation increases hyaluronan production in preadipocytes-fibroblasts; contribution role in hyaluronan accumulation in thyroid dysfunction. Journal of Biological Chemistry $200928426447-26455$. (doi:10.1074/jbc.M109.003616)

30 Liu Z, Sun Y, Dong O. He M, Cheng CH \& Fan F. A novel TSHR gene mutation (Ile691Phe) in a Chinese family causing autosomal dominant non-autoimmune hyperthyroidism. Journal of Human Genetics 200853 475-478. (doi:10.1007/s10038-008-0257-3)

31 Nwosu BU, Gourgiotis L, Gershengorn MC \& Neumann S. A novel activating mutation in transmembrane helix 6 of the thyrotropin receptor as cause of hereditary nonautoimmune hyperthyroidism. Thyroid 200616 505-512. (doi:10.1089/thy.2006.16.505)

32 Vos XG, Smit N, Endert E, Tijssen JG \& Wiersinga WM. Frequency and characteristics of TBII-seronegative patients in a population with untreated Graves' hyperthyroidism: a prospective study. Clinical Endocrinology 200869 311-317. (doi:10.1111/j.13652265.2008.03192.x)

33 Pohlenz J, Pfarr N, Kruger S \& Hesse V. Subclinical hyperthyroidism due to a thyrotropin receptor (TSHR) gene mutation (S505R). Acta Paediatrica 200695 1685-1687. (doi:10.1080/ 08035250600774122 )

34 Nishihara E, Nagayama Y, Amino N, Hishinuma A, Takano T, Yoshida H, Kubota S, Fukata S, Kuma K \& Miyauchi A. A novel thyrotropin receptor germline mutation (Asp617Tyr) causing hereditary hyperthyroidism. Endocrine Journal $2007 \mathbf{5 4} 927-934$. (doi:10.1507/endocrj.K07-088)

35 Fuhrer D, Holzapfel HP, Wonerow P, Scherbaum WA \& Paschke R. Somatic mutations in the thyrotropin receptor gene and not in the $\mathrm{G}_{\mathrm{s}} \alpha$ protein gene in 31 toxic thyroid nodules. Journal of Clinical Endocrinology and Metabolism 199782 3885-3891. (doi:10. 1210/jc.82.11.3885)

36 Akcurin S, Turkkahraman D, Tysoe C, Ellard S, De Leener A, Vassart G \& Costagliola S. A family with a novel TSH receptor activating germline mutation (p.Ala485Val). European Journal of Pediatrics 2008167 1231-1237. (doi:10.1007/s00431-0070659-9)

37 Krohn K \& Paschke R. Somatic mutations in thyroid nodular disease. Molecular Genetics and Metabolism 200275 202-208. (doi:10.1006/mgme.2001.3290)

38 Palos-Paz F, Perez-Guerra O, Cameselle-Teijeiro J, RuedaChimeno C, Barreiro-Morandeira F, Lado-Abeal J, Araujo VD, Argueso R, Barca O, Botana M, Cabezas-Agricola JM, Catalina P, Dominguez GL, Fernandez T, Mato A, Nuno A, Penin M \& Victoria B. Prevalence of mutations in TSHR, GNAS, PRKAR1A and RAS genes in a large series of toxic thyroid adenomas from Galicia, an iodine-deficient area in NW Spain. European Journal of Endocrinology 2008159 623-631. (doi:10.1530/EJE-08-0313)

39 Nishihara E, Amino N, Maekawa K, Yoshida H, Ito M, Kubota S, Fukata S \& Miyauchi A. Prevalence of TSH receptor and $\mathrm{G}_{\mathrm{s}} \alpha$ mutations in 45 autonomously functioning thyroid nodules in Japan. Endocrine Journal 200956 791-798. (doi:10.1507/ endocrj.K09E-073)

40 Kopp P, Muirhead S, Jourdain N, Gu WX, Jameson JL \& Rodd C. Congenital hyperthyroidism caused by a solitary toxic adenoma harboring a novel somatic mutation (serine $281 \rightarrow$ isoleucine) in the extracellular domain of the thyrotropin receptor. Journal of Clinical Investigation $1997 \mathbf{1 0 0}$ 1634-1639. (doi:10.1172/ JCI119687)

41 Deleu S, Allory Y, Radulescu A, Pirson I, Carrasco N, Corvilain B, Salmon I, Franc B, Dumont JE, Van Sande J \& Maenhaut C. 
Characterization of autonomous thyroid adenoma: metabolism, gene expression, and pathology. Thyroid 200010 131-140. (doi:10.1089/thy.2000.10.131)

42 Van Sande J, Lamy F, Lecocq R, Mirkine N, Rocmans P, Cochaux P, Mockel J \& Dumont JE. Pathogenesis of autonomous thyroid nodules: in vitro study of iodine and adenosine $3^{\prime}, 5^{\prime}$-monophosphate metabolism. Iournal of Clinical Endocrinology and Metabolism 198866 570-579. (doi:10.1210/jcem-66-3-570)

43 Ketelbant-Balasse P, Van Sande J, Neve P \& Dumont JE. Time sequence of $3^{\prime}, 5^{\prime}$-cyclic AMP accumulation and ultrastructural changes in dog thyroid slices after acute stimulation by TSH. Hormone and Metabolic Research 19768 212-215. (doi:10.1055/ s-0028-1093662)

44 Van Sande J. Parma J. Tonacchera M. Swillens S, Dumont J \& Vassart G. Somatic and germline mutations of the TSH receptor gene in thyroid diseases. Journal of Clinical Endocrinology and Metabolism 199580 2577-2585. (doi:10.1210/jc.80.9.2577)

45 Voigt C, Holzapfel HP, Meyer S \& Paschke R. Increased expression of G-protein-coupled receptor kinases 3 and 4 in hyperfunctioning thyroid nodules. Journal of Endocrinology 2004182 173-182. (doi:10.1677/joe.0.1820173)

46 van Staveren WC, Solis DW, Delys L, Venet D, Cappello M, Andry G, Dumont JE, Libert F, Detours V \& Maenhaut C. Gene expression in human thyrocytes and autonomous adenomas reveals suppression of negative feedbacks in tumorigenesis. PNAS $2006 \mathbf{1 0 3}$ 413-418. (doi:10.1073/pnas.0507354102)

47 Arseven OK, Wilkes WP, Jameson JL \& Kopp P. Substitutions of tyrosine 601 in the human thyrotropin receptor result in increase or loss of basal activation of the cyclic adenosine monophosphate pathway and disrupt coupling to $\mathrm{G}_{\mathrm{q} / 11}$. Thyroid $2000 \mathbf{1 0} 3-10$. (doi:10.1089/thy.2000.10.3)

48 Biebermann H, Schoneberg T, Schulz A, Krause G, Gruters A, Schultz G \& Gudermann T. A conserved tyrosine residue (Y601) in transmembrane domain 5 of the human thyrotropin receptor serves as a molecular switch to determine G-protein coupling. FASEB Journal 199812 1461-1471.

49 Rosenthal D. Kinetic analysis of iodine and thyroxine metabolism in "hot" thyroid nodules. Metabolism 198130 384-392. (doi:10. 1016/0026-0495(81)90120-7)

50 Moreno-Reyes R, Tang BN, Seret A, Goldman S, Daumerie C \& Corvilain B. Impaired iodide organification in autonomous thyroid nodules. Journal of Clinical Endocrinology and Metabolism 200792 4719-4724. (doi:10.1210/jc.2007-0833)

51 Parma J, Duprez L, Van Sande J, Hermans J, Rocmans P, Van Vliet G, Costagliola S, Rodien P, Dumont JE \& Vassart G. Diversity and prevalence of somatic mutations in the thyrotropin receptor and $\mathrm{G}_{\mathrm{s}} \alpha$ genes as a cause of toxic thyroid adenomas. Journal of Clinical Endocrinology and Metabolism 199782 2695-2701. (doi:10.1210/jc.82.8.2695)

52 Ledent C, Coppee F, Dumont JE, Vassart G \& Parmentier M. Transgenic models for proliferative and hyperfunctional thyroid diseases. Experimental and Clinical Endocrinology and Diabetes 1996 104 (Supplement 3) 43-46. (doi:10.1055/s-0029-1211683)

53 Dumont JE, Lamy F, Roger P \& Maenhaut C. Physiological and pathological regulation of thyroid cell proliferation and differentiation by thyrotropin and other factors. Physiological Reviews 199272 667-697.

54 Kero J, Ahmed K, Wettschureck N, Tunaru S, Wintermantel T, Greiner E, Schutz G \& Offermanns S. Thyrocyte-specific $G_{q} / G_{11}$ deficiency impairs thyroid function and prevents goiter development. Journal of Clinical Investigation 2007117 2399-2407. (doi:10.1172/JCI30380)

55 Grasberger H, Van Sande J, Hag-Dahood MA, TenenbaumRakover Y \& Refetoff S. A familial thyrotropin (TSH) receptor mutation provides in vivo evidence that the inositol phosphates/ $\mathrm{Ca}^{2+}$ cascade mediates TSH action on thyroid hormone synthesis. Journal of Clinical Endocrinology and Metabolism 2007 92 2816-2820. (doi:10.1210/jc.2007-0366)

56 Winkler F, Kleinau G, Tarnow P, Rediger A, Grohmann L, Gaetjens I, Krause G, L'Allemand D, Gruters A, Krude H \& Biebermann H. A new phenotype of nongoitrous and nonautoimmune hyperthyroidism caused by a heterozygous thyrotropin receptor mutation in transmembrane helix 6. Journal of Clinical Endocrinology and Metabolism 201095 3605-3610. (doi:10. 1210/jc.2010-0112)

57 Van Keymeulen A, Bartek J, Dumont JE \& Roger PP. Cyclin D3 accumulation and activity integrate and rank the comitogenic pathways of thyrotropin and insulin in thyrocytes in primary culture. Oncogene 199918 7351-7359. (doi:10.1038/sj.onc. 1203164)

58 Mastorakos G, Mitsiades NS, Doufas AG \& Koutras DA. Hyperthyroidism in McCune-Albright syndrome with a review of thyroid abnormalities sixty years after the first report. Thyroid $1997 \mathbf{7}$ 433-439. (doi:10.1089/thy.1997.7.433)

59 Rodien P, Bremont C, Sanson ML, Parma J, Van Sande J, Costagliola S, Luton JP, Vassart G \& Duprez L. Familial gestational hyperthyroidism caused by a mutant thyrotropin receptor hypersensitive to human chorionic gonadotropin. New England Journal of Medicine 1998339 1823-1826. (doi:10.1056/ NEJM199812173392505)

60 Corbetta C, Weber G, Cortinovis F, Calebiro D, Passoni A, Vigone MC, Beck-Peccoz P, Chiumello G \& Persani L. A 7-year experience with low blood TSH cutoff levels for neonatal screening reveals an unsuspected frequency of congenital hypothyroidism (CH). Clinical Endocrinology 200971 739-745. (doi:10.1111/j. 1365-2265.2009.03568.x)

61 Krohn K, Wohlgemuth S, Gerber H \& Paschke R. Hot microscopic areas of iodine-deficient euthyroid goitres contain constitutively activating TSH receptor mutations. Journal of Pathology 2000192 37-42. (doi:10.1002/1096-9896(2000) 9999:9999<::AID-PATH650 > 3.0.CO;2-3)

62 Mueller S, Gozu HI, Bircan R, Jaeschke H, Eszlinger M, Lueblinghoff J, Krohn K \& Paschke R. Cases of borderline in vitro constitutive thyrotropin receptor activity: how to decide whether a thyrotropin receptor mutation is constitutively active or not? Thyroid 200919 765-773. (doi:10.1089/thy.2009.0006)

63 Elgadi A, Zemack H, Marcus C \& Norgren S. Tissue-specific knockout of TSHr in white adipose tissue increases adipocyte size and decreases TSH-induced lipolysis. Biochemical and Biophysical Research Communications 2010393 526-530. (doi:10.1016/j. bbrc.2010.02.042)

64 Rubin CJ, Zody MC, Eriksson J, Meadows JR, Sherwood E, Webster MT, Jiang L, Ingman M, Sharpe T, Ka S, Hallbook F, Besnier F, Carlborg O, Bed'hom B, Tixier-Boichard M, Jensen P, Siegel P, Lindblad-Toh K \& Andersson L. Whole-genome resequencing reveals loci under selection during chicken domestication. Nature 2010464 587-591. (doi:10.1038/nature08832)

65 Sun SC, Hsu PJ, Wu FJ, Li SH, Lu CH \& Luo CW. Thyrostimulin, but not thyroid-stimulating hormone (TSH), acts as a paracrine regulator to activate the TSH receptor in mammalian ovary. Journal of Biological Chemistry 2010285 3758-3765. (doi:10. 1074/jbc.M109.066266)

Received 4 October 2010

Accepted 6 October 2010 